\title{
THE GEOLOGY AND STRUCTURE OF NEOGENE ROCKS IN DADYAL AND ADJACENT AREAS, IN THE SUB-HIMALAYAS, AZAD JAMMU AND KASHMIR, PAKISTAN
}

\author{
Ahmer Bilal, Muhammad Yasin*, Ahtasham Ali ${ }^{1}$ \\ *Institute of Geology, University of Azad Jammu and Kashmir, Muzaffarabad, Pakistan. \\ 1 Department of Earth \& Environmental Sciences, Bahria University, Islamabad, Pakistan. \\ *Corresponding Author: Rajayasinkhan@gmail.com
}

This is an open access article distributed under the Creative Commons Attribution License, which permits unrestricted use, distribution, and reproduction in any medium, provided the original work is properly cited

\section{ARTICLE DETAILS}

\section{Article history:}

Received 24 October 2016

Accepted 7 December 2016

Available online 3 January 2017

Keywords:

Hazara Kashmir Syntaxis

Neogene rocks Vergent

Trending

\section{ABSTRACT}

The project area lies along the western limb of the Hazara Kashmir Syntaxis. The Hazara Kashmir Syntaxis is an antiformal structure. The project area includes Dadyal, Bihari, Ratta, Sammorthala, Samlotha, Dhingar, Panwar and Karara Saiyidan. The Late Miocene to Recent Himalayan Neogene rocks are exposed in the core of the syntaxis. These Neogene rocks include the Kamlial Formation, Chinji Formation, Nagri Formation, Dhok Pathan Formation, Soan Formation and Recent alluvium. The major folds in the project area include the Mirpur syncline, Pheran Dinpur anticline and Sadaqabad Syncline. The folds are northwest-southeast trending and southwest or northeast vergent, asymmetric and open. The only fault in the project area is Ratta Fault. The Ratta Fault is a reverse fault. The northwest southeast trending folds and faults are the result of northeast southwest Himalayan compression in the area.

\section{Introduction}

The project area in Dadyal, Mirpur district of Azad Jammu and Kashmir, Pakistan is confined in the east, west and south by the Riasi thrust, Jhelum fault and Salt Range thrust respectively (Fig. 1). The location of study area in the western limb of the Hazara Kashmir Syntaxis is shown on the tectonic map (Fig. 1).

The Dadyal, Bihari, Ratta, Sammorthala, Dhinger, Panwar, and Karara Saiyidan area are mapped on the toposheet 43/G-11, Survey of Pakistan. The areas lying at coordinates $73^{\circ} 38^{\prime} 50^{\prime \prime} \mathrm{E}$ to $73^{\circ} 45^{\prime} 00^{\prime \prime} \mathrm{E}$ and $33^{\circ}{ }^{\circ} 15^{\prime}$ $00^{\prime \prime} \mathrm{N}$ to $33^{\circ} 23^{\prime} 00^{\prime \prime} \mathrm{N}$ are well known for fertile land, forests and the frequent occurrence of mountains. The Jhelum river in the area has been haRnessed to form Mangla Reservoir.

The Nagri Formation, Dhok Pathan Formation, Soan Formation, Mirpur Formation and recent alluvium are well exposed in the area.

\section{Previous work}

The Mirpur and adjoining areas were previously surveyed by different geologists (Ledekker, 1876; Wadia, 1928; Chuhdary and Ashraf, 1983; Chaudhary and Ashraf, 1984; Baig and Lawrence, 1987; Wells and Gingerich, 1987; Akhtar et al., 2004; Munir and Baig, 2006) before the commencement of project in the area (Yasin, 2012) .

\section{Materials and methods}

The city, adjacent areas of Mangla reservoir, recondite places and lonely desolate valleys were surveyed in mild weather with utmost care during 30 days field work. The field photographs (Fig. 5) were taken by means of a digital camera. The rock Formations were mapped by using Brunton compass during onerous task (Fig. 3). In addition, the instrument was also used to record the attitude of bedding (Fig. 3). The route and traverse, geological and structural maps of the $75 \mathrm{~km} 2$ area on 1:50,000 scale were compiled (Fig. 2). Moreover, the detailed structural crosssections and $\beta$ and $\pi$ diagrams were prepared for the structural analysis of the area (Fig. 5). The primary sedimentary structures remained helpful in the identification of the facing of rock units (Fig. 4a). The data used in structural interpretation has been enumerated in the tables $1 \& 2$.

\section{Results and Discussions}

\subsection{Stratigraphy}

The geological succession of the Dadyal and adjacent areas of Mirpur is presented in Table 3. The rocks of the project area (Table. 4) are described as follows:

\subsubsection{Siwalik Group}

Meddlicot, 1864 first used the term "Siwalik" to describe the upper part of the "Sub-Himalayan System". The Siwalik Group is comprised of Neogene rocks, deposited during the Himalayan orogeny. The Siwalik Group contains arenaceous, argillaceous and conglomeratic material. The following rock sequence of Siwalik group is exposed in the project area.

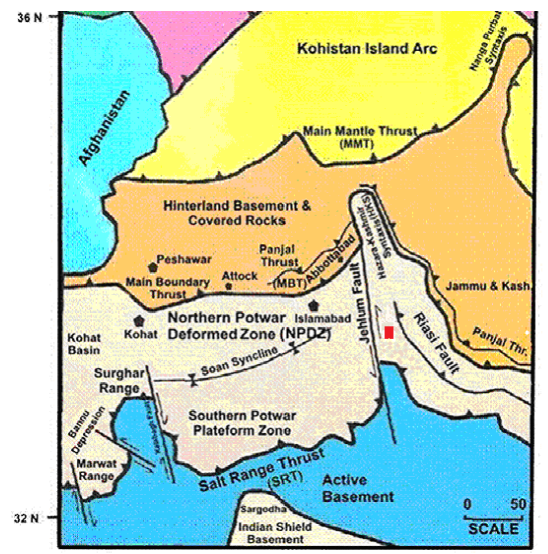

Figure 1. Regional tectonic map of the northwest Himalayas of Pakistan after (Baig and Lawrence, 1987; Monalisa and Khawaja, 2004. The rectangle shows the location of the project area. 


\section{- Soan Formation}

- Dhok Pathan Formation

- Nagri Formation

\subsubsection{Nagri Formation}

The "Nagri Formation" was accepted by the Stratigraphic committee of Pakistan after Lewis (937). The Nagri Formation is mapped in Goda Sultana, Karara Saiyidan and Jinour areas (Fig. 2; Fig. 3). The sandstone and clays (60 to $40 \%$ ) are the dominant lithologies of the Formation. The sandstone is greenish gray, weathered to light gray and brownish gray in outcrops. In addition, the sandstone is medium to coarse grained, hard, compact, medium to thick bedded and massive. Furthermore, the sandstone is cross bedded and exhibits salt and pepper texture (Fig. 4b). The clays vary in colour from cream to light gray. The clays are soft and friable. The mudstone and gritty clays are in scanty amount.

The minerals quartz, feldspar, biotite, epidote, muscovite, tourmaline, plagioclase and garnet coexist in the rock. The biotite is in excess amount. The pink garnet and Panjal volcanic clasts are highly concentrated towards the top of the Formation. The clasts of granite, quartzite and marble are also disseminated in the outcrop. The formation has a high concenteration of epidote and biotite than Kamlial Formation. The formation has gradational contacts with the Dhok Pathan and Chinji Formations in the upper and lower halves respectively.

The earlier workers assigned Late Miocene age to the Formation (Shah, 2009).

\subsubsection{Dhok Pathan Formation}

The term "Dhok Pathan" of Pilgrim (Pilgrim, 1913) was redefined by Cotter (1913) as the "Dhok Pathan Formation" and finally approved by the Stratigraphic Committee of Pakistan (Shah, 2009).

The Formation is mapped in Bihari, Karara Sayidan, Khurd Piran Goda and Panwar areas (Fig. 2; Fig. 3). The sandstone, clay (50:50) and hard compact conglomeratic beds form the composition of rock. The sandstone is medium to coarse grained, soft, porous, friable (Fig. 4d) and less compact as compare to the sandstone of Nagri Formation. The conglomeratic levels are thick, hard and compact. The cross bedding (Fig. 4a), rip ups, lenticular bedding and ribbed topography (Fig. 4c) are the non tectonic structures of Dhok Pathan Formation. The clays are red and maroon in outcrops. The clasts vary in size from $2 \mathrm{~mm}$ to $5 \mathrm{~cm}$ diameter.

The minerals quartz, feldspar, muscovite, pink garnet, brown garnet, epidote, minor biotite and tourmaline form the mineral composition of the Dhok Pathan Formation. The ribbed topography (Fig. 4c) and presence of pink garnet distinguish the Dhok Pathan Formation from the rest of Formations.

The contacts with the overlying and underlying formations are gradational. However, in Ratta the formation has a faulted contact with Soan Formation (Fig 2; Fig. 3). The earlier workers declared Late Miocene age to the Formation (Shah, 2009).

\subsubsection{Soan Formation}

The Stratigraphic Committee of Pakistan has approved the name Soan Formation following Kravchenko (1964).

The sandstone, dark gray shale and conglomerates are the dominant constituents of the Soan Formation. The compact, thick, hard and massive conglomerate levels are ubiquitous near Dingar, Anb and Dadyal. The conglomerates include the pebbles and boulders of quartzite, Panjal volcanics, Murree sandstone, Paleocene-Eocene limestone, cherty dolomite and granite gneisses. The conglomerates are tesselated in arenaceous matrix (Fig. 4e). The pebbles and boulders have rounded to sub rounded outlines, few $\mathrm{mm}$ to $30 \mathrm{~cm}$ diameters and the thickness of about 0.5 meter has been paced out in the lenticular sandy layers (Fig. 4e). The sandstone lenses are exposed in Siakh (Fig. 4e), near Samlotha, Pagal Chak and Dadyal.

The contact of Soan Formation with Dhok Pathan Formation is faulted in project area (Fig. 4h), graditional in other areas and sharp (angular) with Mirpur Formation in the Mirpur area. The earlier workers proposed Pliocene age to the Formation (Shah, 2009).

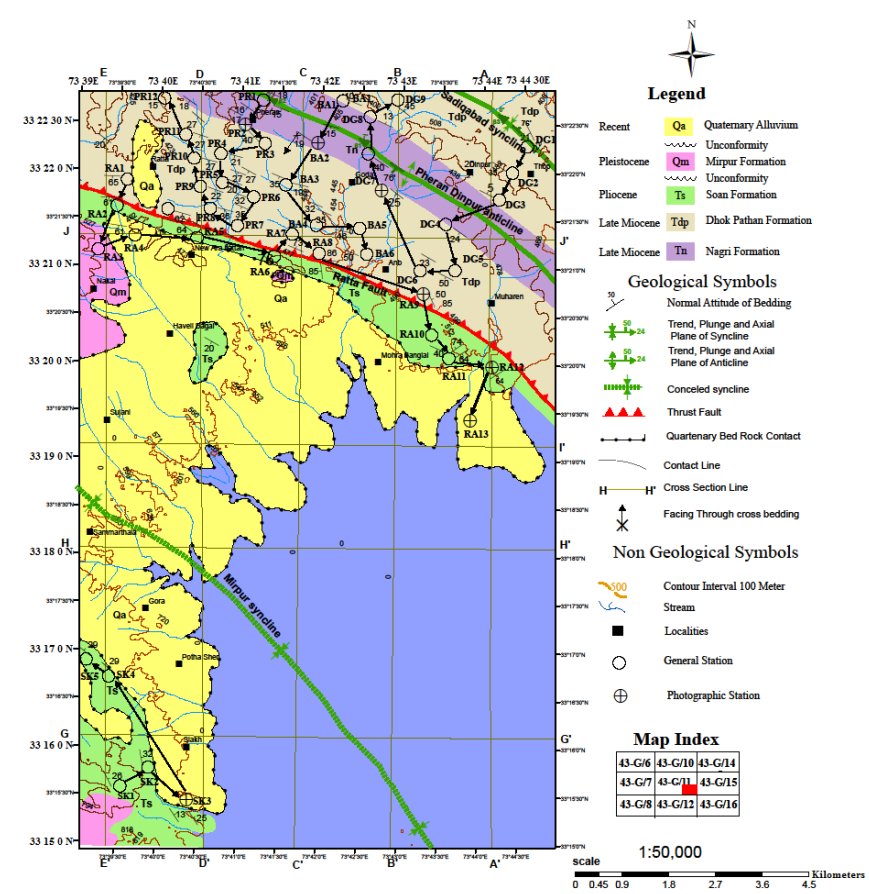

Figure 2. Route and Traverse Map of Ratta, Behari, Dadyal area, District Mirpur, Azad Kashmir, Pakistan.

\subsubsection{Mirpur Formation}

The Formation is mapped in the Sammorthala, Ratta, Siakh, Nakai and Dadyal areas (Fig. 2; Fig.3). The formation is a Pleistocene flood or channels fill deposit. The framework grains are loosely packed within the argillaceous matrix (Fig. 4f). The clast varies in size from $2 \mathrm{~mm}$ to $30 \mathrm{~cm}$ diameter (Fig. 4f).

These conglomerates followed the topography of the underlying formation and appear as a blanket over the bed rocks. The upper contact with recent alluvium and lower contact with Soan Formation are unconformable. The Mirpur Formation can be distinguished from the Soan formation by argillaceous cement. The age of the formation is Pleistocene (Shah, 2009).

\subsubsection{Recent Alluvium}

The fresh water deposits are mapped in the Mohra Bangial, Ratta, Sammorthala, Siakh, Potha Bangash, Potha Sher, Mughal Pura and Bihari areas (Fig. 2; Fig. 3). The deposits contain rounded to subrounded gravel, sand, silt and clay. These deposits are less compact (Fig. 4g). The alluvium marks an unconformity on the top of Mirpur Formation.

\subsection{Structure}

The project area is surrounded by the Jhelum Fault, Riasi Fault and Salt Range Thrust in the western, eastern and southern directions, respectively (Fig. 1). The area is exposed in the south of Hazara Kashmir Syntaxis and is highly deformed by Himalayan orogeny (Fig. 1). The Hazara Kashmir Syntaxis (Fig. 1) is an antiformal structure formed by the abrupt change in northwest regional strike of the Himalayan thrust sheets to the northeast. The Main Boundry Thrust and Panjal Thrust show contortion around the Hazara Kashmir Syntaxis (Fig. 1). The folds in the project area are northwest-southeast trending, open and northeast or southwest vergent (Tables, 1 \& 2).

\subsubsection{Structure of the area}

The Tertiary to Recent cover sequence of Indian Plate is deformed into folds and faults (Fig. 1). The structures is described as follows:

\subsubsection{Folds \\ There are three following major folds in the area. \\ - $\quad$ Pheran Dinpur Anticline \\ - $\quad$ Sadiqabad Syncline \\ - $\quad$ Mirpur Syncline}

\subsubsection{Pheran Dinpur Anticline}

The Pheran Dinpur anticline is formed by the folding of Nagri and Dhok Pathan Formations (Fig. 2; Fig. 3). The Nagri Formation forms the core whereas the Dhok Pathan Formation forms the limbs of the fold (Fig. 5, cross section $\mathrm{JJ}^{\prime}$ ). The southwestern limb of the Pheran Dinpur anticline is displaced by the Ratta fault (Fig. 5, cross sections $\mathrm{AA}^{\prime}, \mathrm{BB}^{\prime}, \mathrm{CC}^{\prime}, \mathrm{DD}^{\prime}, \mathrm{JJ}$ 
The Chinji and Kamlial Formations confront in the subsurface (Fig. 5, cross-sections $\left.\mathrm{AA}^{\prime}, \mathrm{BB}^{\prime}, \mathrm{CC}^{\prime}, \mathrm{DD}^{\prime}, \mathrm{JJ}^{\prime}\right)$. The strike of northeast limb displays orientation in $\mathrm{N}^{\circ} 2^{\circ} \mathrm{W}$ to $\mathrm{N}^{\circ} 9^{\circ} \mathrm{W}$ whereas the strike of the southwestern limb exhibits orientation in $\mathrm{N} 29^{\circ} \mathrm{W}$ to $\mathrm{N} 58^{\circ} \mathrm{W}$ direction. The northeastern limb of fold dips at $10^{\circ} \mathrm{NE}$ to $50^{\circ} \mathrm{NE}$ whereas the southwestern limb of fold dips at $24^{\circ} \mathrm{SW}$ to $40^{\circ} \mathrm{SW}$ (Table. 1). The attitude of the axial plane is slanted in $\mathrm{N} 30^{\circ} \mathrm{W} 80^{\circ} \mathrm{SW}$ to $\mathrm{N} 72^{\circ} \mathrm{W} / 77^{\circ} \mathrm{SW}$ directions (Table. 1; Fig. 6,).

The fold axis of the anticline trend and plunge at $5^{\circ} / 330^{\circ}$ to $7^{\circ} / 288^{\circ}$ (Table, 1). The interlimb angle of the fold varies between $106^{\circ}$ to $120^{\circ}$. On the basis of interlimb angle, the fold is classified as an open fold. The Pheran Dinpur anticline is northeast verging fold. The regional anticline is interpreted as hanging wall anticline, formed along the Ratta Fault (Fig. 5; cross sections $\mathrm{AA}^{\prime}, \mathrm{BB}^{\prime}, \mathrm{CC}^{\prime}, \mathrm{DD}^{\prime}, \mathrm{JJ}^{\prime}$ ).

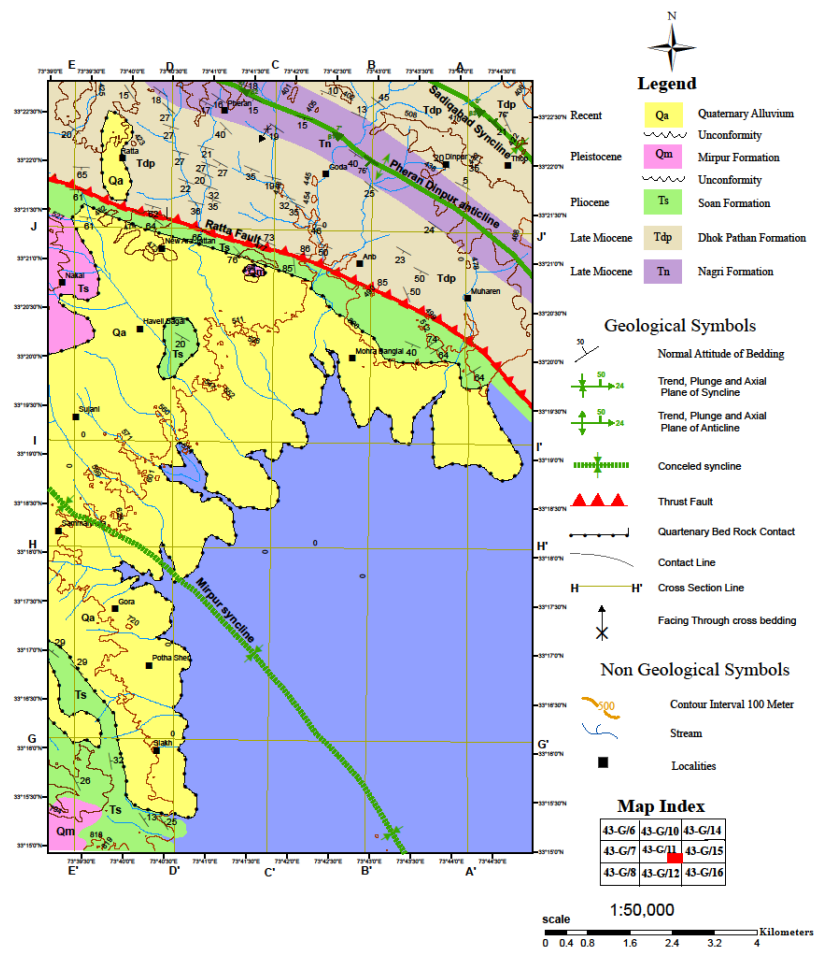

Figure 3. The composite Geological and structural map of Ratta, Behari and Dadyal areas, District Mirpur,Azad Kashmir, Pakistan.

\subsubsection{Sadiqabad Syncline}

The Sadiqabad syncline is a regional syncline formed by the folding of Dhok Pathan and Nagri Formations. The Dhok Pathan Formation lies in the core whereas Nagri Formation forms the limbs (Fig. 5, cross sections $\mathrm{AA}^{\prime}, \mathrm{BB}^{\prime}, \mathrm{CC}^{\prime}, \mathrm{DD}^{\prime}$ )

The strike of the northeastern limb is oriented in $\mathrm{N} 26^{\circ} \mathrm{W}$ whereas the strike of the south western limb is oriented in $\mathrm{N} 30^{\circ} \mathrm{W}$ direction. The northeastern limb of syncline dips at $08^{\circ} \mathrm{SW}$ whereas southwestern limb dips at $15^{\circ} \mathrm{NE}$. The Sadiqabad syncline exhibits a trend and plunge of $0^{\circ} / 334^{\circ}$. The attitude of axial plane falls in $\mathrm{N} 26^{\circ} \mathrm{W} / 85^{\circ} \mathrm{SW}$ direction Table. 2; Fig. 6). The Sadiqabad syncline has an interlimb angle of about $157^{\circ}$ (Table, 2; Fig. 6). On the basis of interlimb angle the fold is classified as gentle fold. The Sadiqabad syncline is northeast vergent fold.

\subsubsection{Mirpur Syncline}

Mirpur syncline is regional syncline formed by the folding of Soan Formation. In project area, the Mangla reservoir and Quaternary alluvium has concealed the syncline. (Fig. 2; Fig. 3: cross sections $\mathrm{AA}^{\prime}$, $\left.\mathrm{BB}^{\prime}, \mathrm{CC}^{\prime}, \mathrm{DD}^{\prime}, \mathrm{JJ}^{\prime}\right)$.
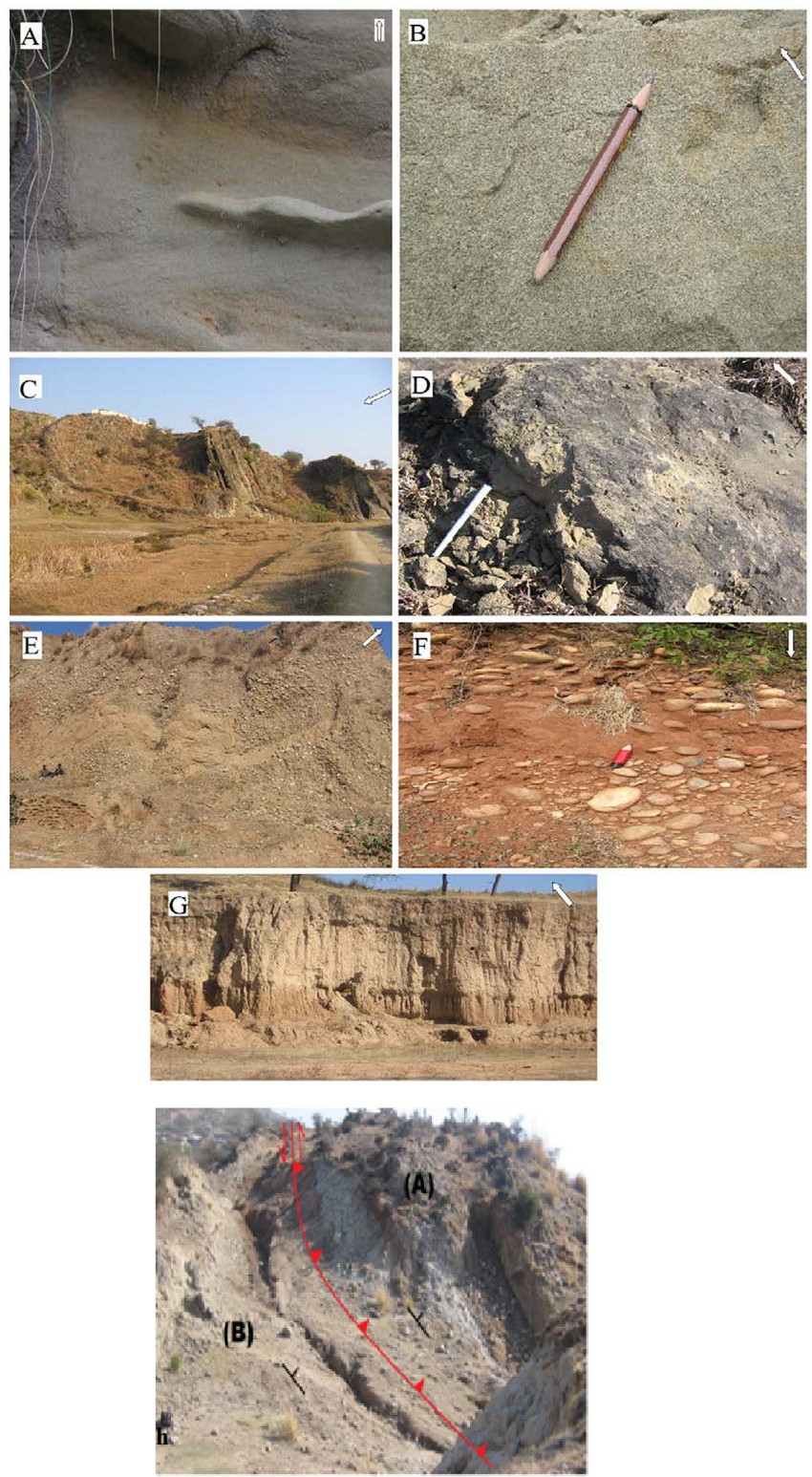

Figure 4. (a) Photograph showing cross bedded sandstone of Nagri Formation near Pheran (photo facing south), (b) showing salt and pepper texture in the sandstone of Nagri Formation near Pheran (Photo facing southwest), (c) Photograph showing ribbed topography (cyclic bedding) in Dhok Pathan formation near Goda (Photo facing southwest), (d) Photograph showing loosely compacted sandstone of Lower Soan Formation, Mohra Bangial (Photograph facing southwest), (e) Photograph showing lenses of tesselated conglomerate in upper Soan Formation near Siakh (Photo facing south east), (f) Photograph showing conglomerates of Mirpur Formation near Nakai (Photo facing North), (g) Photograph showing thick layer of recent alluvium near Mohra Bangial (Photo facing southwest), Photograph showing Ratta fault between Dhok Pathan Formation (A) and Soan Formation (B) near Anb (Photograph facing south).

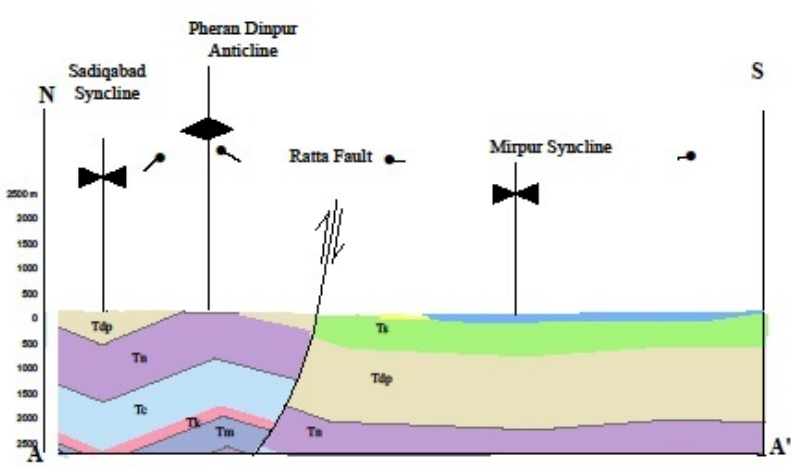



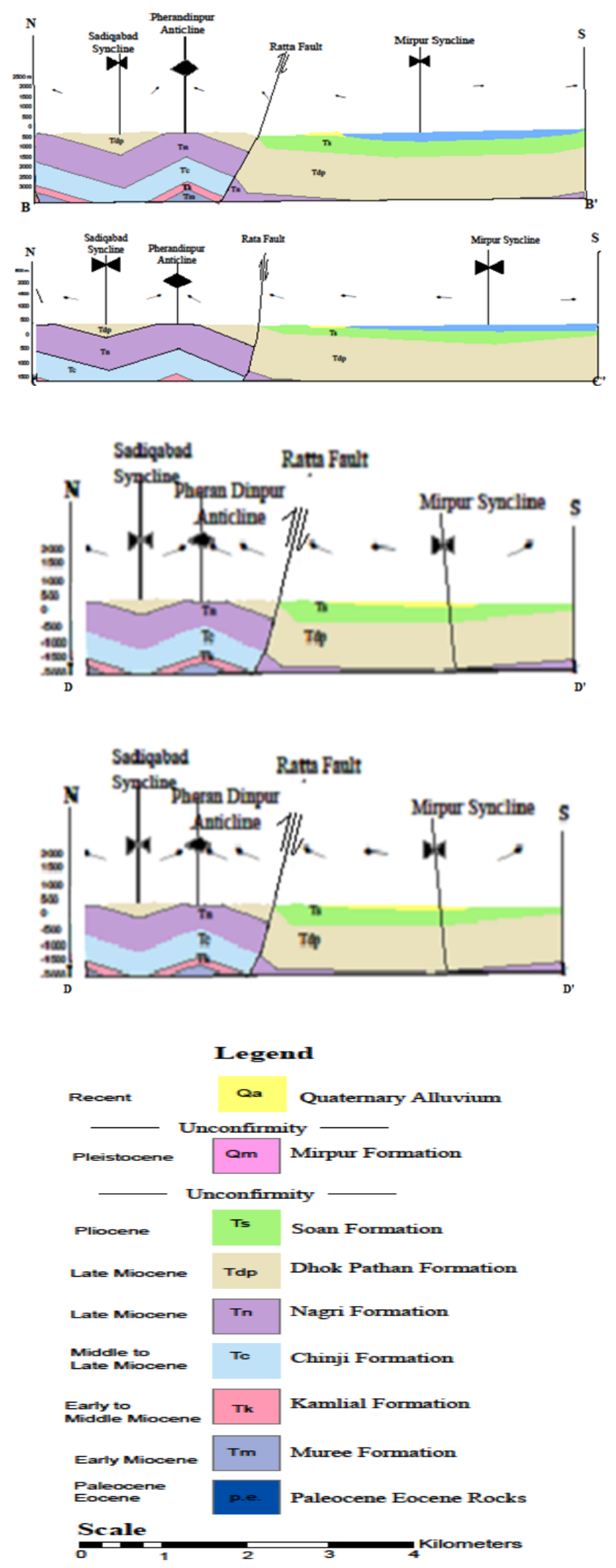

Figure 5. $\mathrm{AA}^{\prime}, \mathrm{BB}^{\prime}, \mathrm{CC}^{\prime}, \mathrm{DD}^{\prime}, \mathrm{JJ}^{\prime}$, Structural cross sections of Sadiqabad, Ratta area and adjacent areas through the profiles on map, District Mirpur, Azad Kashmir, Pakistan.

\subsubsection{Faults}

There is only one major fault in the area called as Ratta Fault.

\subsubsection{Ratta Fault}

The Ratta Fault is a northwest-southeast trending reverse fault and has displaced the southeastern limb of Pheran Dinpur anticline (Fig. 2; Fig. 3). In the project area, the Dhok Pathan Formation thrusts over the Soan Formation (Fig. 2; Fig. 3; cross sections $\mathrm{AA}^{\prime}, \mathrm{BB}^{\prime}, \mathrm{CC}^{\prime}, \mathrm{DD}^{\prime}$ and $\mathrm{JJ}^{\prime}$ ). The attitude of the hanging wall falls in $\mathrm{N} 45^{\circ} \mathrm{W} / 23^{\circ} \mathrm{NE}$ to $\mathrm{N} 55^{\circ} \mathrm{W} / 35^{\circ}$ $\mathrm{NE}$ directions and the attitude of footwall block falls in $\mathrm{N} 48^{\circ} \mathrm{W} / 32^{\circ} \mathrm{NE}$ directions. The attitude of the fault plane is about $\mathrm{N} 70^{\circ} \mathrm{W} / 85^{\circ} \mathrm{NE}$ (Fig. 4h). The Ratta Fault is a reverse fault (Fig. 4h).

The shearing, crushing (Fig. 4h), fault breccia, gouge and drag folding are the clues of deformation along the Ratta Fault.

Table 1. Structural interpretations of Pheran Dinpur Anticline.

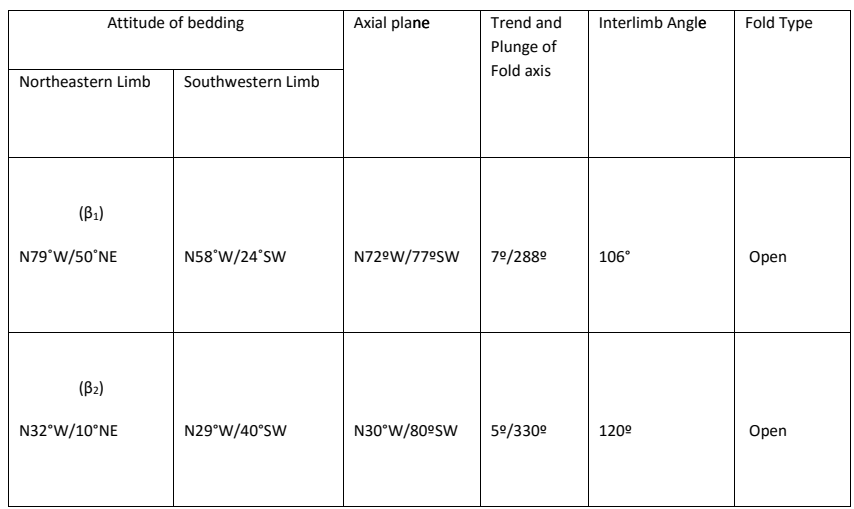

Table 2. Structural interpretations of Sadiqabad Syncline.

\begin{tabular}{|c|c|l|l|l|l|}
\hline \multicolumn{2}{|c|}{ Attitude of Bedding } & Axial Plane & $\begin{array}{l}\text { Trend and } \\
\text { Plunge of } \\
\text { Fold axis }\end{array}$ & $\begin{array}{l}\text { Interlimb } \\
\text { Angle }\end{array}$ & Fold Type \\
\hline $\begin{array}{c}\text { Northeastern } \\
\text { Limb }\end{array}$ & $\begin{array}{c}\text { Southwestern } \\
\text { Limb }\end{array}$ & N26 $\mathrm{W} / 85^{\circ} \mathrm{W}$ & $00 / 3340$ & $157^{\circ}$ & Gentle \\
\hline $\begin{array}{c}\left(\beta_{3}\right) \\
\mathrm{N} 26 \mathrm{~W}^{\circ} / 08 \mathrm{SW}\end{array}$ & $\mathrm{N} 30 \mathrm{~W}^{\circ} / 15 \mathrm{NE}$ & $\mathrm{N} 6^{\circ}$ & \\
\hline
\end{tabular}
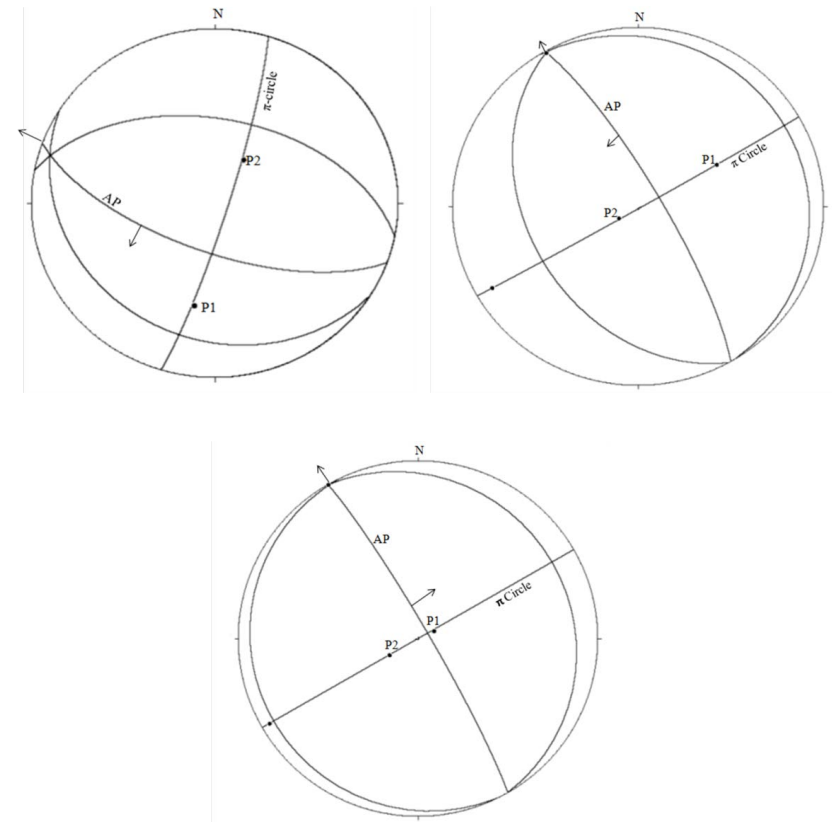

Figure. 6: The $\pi$ and $\beta$ diagram of Pheran Dinpur anticline (1st and 2 nd) and $\beta$ diagram of Sadiqabad syncline (3rd).

Table 3. The Geological succession of the Mirpur and adjoining areas (Yasin, 2012). 


\begin{tabular}{|c|c|c|}
\hline Formation & Age & Description \\
\hline Quaternary alluvium & Recent & Consist of unconsolidated deposits of clay silt, gravel. \\
\hline Mirpur Formation & Pleistocene & $\begin{array}{l}\text { Poorly sorted conglomerates consisted of pebbles, cobbles of igneous, } \\
\text { metamorphic and sedimentary rocks. }\end{array}$ \\
\hline$\cdots \cdots \cdots \cdots$ & formity.......... & \\
\hline Soan Formation & 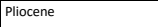 & Conglomerates, Brown, yellow gray clays and claystone, gray sandstone. \\
\hline Dhok Pathan Formation & Late Miocene & $\begin{array}{l}\text { Dominantly consists of sandstone, siltstone and clays. Sandstone is grey, } \\
\text { fine to medium grained and medium to thick beddded. }\end{array}$ \\
\hline Nagri Formation & Late Miocene & $\begin{array}{l}\text { Dominantly, consists of greenish grey sandstone, sittstone and mudstone. } \\
\text { Sandstone has massive beds and has medium to coarse grained texture. } \\
\text { Sandstone alternates with clay and are } 60 \% \text { and } 40 \% \text { respectively. }\end{array}$ \\
\hline Chingi Formation & Middle to late Miocene & $\begin{array}{l}\text { Red to purple, greenish grey, ash grey sandstone and siltstone and purple } \\
\text { and reddish brown mudstone. } 60 \% \text { clays and } 40 \% \text { sandstone. }\end{array}$ \\
\hline Kamlial Formation & Early to middle Miocene & Mainly sandstone, clays and intraformational conglomerates. \\
\hline Murree Formation & Early Miocene & $\begin{array}{l}\text { Mostly clays, shales and sandstone. Sandstone is red to purple red in colour } \\
\text { and is fine to medium grained. }\end{array}$ \\
\hline Kuldana Formation & Middle to Late Eocene & Variegated shales with subordinate sandstone. Shales are arenaceous. \\
\hline Chorgali Formation & Early Eocene & $\begin{array}{l}\text { Mostly Calcareous shale, nodular limestone and dolomitic limestone, clays } \\
\text { and quartzite. }\end{array}$ \\
\hline Margalla Hill Limestone & Early Eocene & Main nodular fossiliferous limestone with shales. \\
\hline Patala Formation & Late Paleocene & Mainly shales with interbedded limestone. \\
\hline Lockhart formation & Early Paleocene & Grey to dark grey limestone with subordinate shales. \\
\hline Hangu Formation & Early Paleocene & Mainly Laterite, bauxite and fireclay. \\
\hline Muzaffarabad Formation & Cambrian & Mainly Dolomitic limestone with cherty dolomite and chert bands. \\
\hline Dogra Formation & Precambrian & Slates, phyllite and shales with limestone. \\
\hline
\end{tabular}

Table 4. The stratigraphic sequence of the study area.

\begin{tabular}{|c|c|c|}
\hline $\begin{array}{l}\text { Formatio } \\
n\end{array}$ & Age & Description \\
\hline Alluvium & Recent & $\begin{array}{l}\text { Unconsolidated deposit of clay, gravel, pebble } \\
\text { etc. }\end{array}$ \\
\hline \multicolumn{3}{|l|}{ 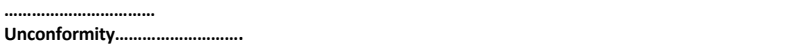 } \\
\hline Mirpur Formation & Pleistocene & $\begin{array}{l}\text { Poorly sorted conglomerates consisted of pebbles, } \\
\text { cobbles of igneous, sedimentary and metamorphic } \\
\text { rocks. }\end{array}$ \\
\hline \multicolumn{3}{|l|}{ 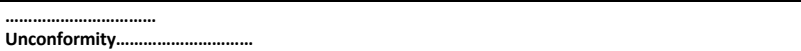 } \\
\hline Soan Formation & Pliocene & $\begin{array}{l}\text { Conglomerate levels are high very thick, hard and } \\
\text { compact. Conglomerates constitute the fragments } \\
\text { of cherty dolomite, panjal volcanics, granite, } \\
\text { gneisses and compact arenaceous matrix. Bentonite } \\
\text { is present in lower bed. }\end{array}$ \\
\hline $\begin{array}{l}\text { Dhok Pathan } \\
\text { Formation }\end{array}$ & Late Miocene & $\begin{array}{l}50 \% \text { sandstone and } 50 \% \text { clay, cyclic bedding, ribbed } \\
\text { topography, flaser or lenticular bedding presents, } \\
\text { hard and compact conglomerate beds are present, } \\
\text { pink garnet also appears. }\end{array}$ \\
\hline Nagri Formation & Late Miocene & $\begin{array}{l}70 \% \text { sandstone and } 30 \% \text { clay present. Sandstone is } \\
\text { hard and compact, volcanic clasts are also present in } \\
\text { upper part. Spheroidal weathering is also present. }\end{array}$ \\
\hline
\end{tabular}

\section{Discussion}

The project area exists in the southern part of Hazara Kashmir Syntaxis. The Hazara Kashmir Syntaxis is an antiformal structure, formed by the late Tertiary Himalayan collision between the Indian and Eurasian plates. The southeastern limb of the Hazara syntaxis is imbricated along Punjal Thrust, Main Boundary Thrust and Riasi Fault (Baig and Lawrence, 1987). The western limb of the Hazara Kashmir Syntaxis is displaced by left lateral strike slip Jhelum Fault.

The core of syntaxis is comprised of a deformed zone. The deformed zone makes a domal structure due to the layer compression (Bossart et al., 1988). The Himalayan neogene rocks form the core of syntaxis. These rocks represent the part of cover sequence of Indian plate.

The Late Miocene to recent deposits in the study area include the Nagri Formation, Dhok Pathan Formation, Soan Formation, Mirpur Formation and Recent alluvium. The area is highly deformed into regional folds and faults. The folds and faults are northwest southeast trending. The folds of the area are southwest or northeast vergent. The folds are open to tight in nature. The major folds include Pheran Dinpur anticline, Sadiqabad syncline and Mirpur syncline. The Pheran Dinpur anticline is formed by the folding of Nagri Formation (Fig. 2; Fig. 3; Cross sections, $\mathrm{AA}^{\prime}, \mathrm{BB}^{\prime}, \mathrm{CC}^{\prime}$ and $\mathrm{JJ}^{\prime}{ }^{\prime}$ ). The southwestern limb of the anticline is relatively steeper than the northeastern limb (Table. 1). The Pheran Dinpur anticline is an open and southwest verging asymmetric fold. The Pheran Dinpur anticline is a plunging fold.

The Sadiqabad syncline is a regional syncline formed by the folding of Dhok Pathan Formation and Nagri Formation. The Dhok Pathan Formation is in the core whereas Nagri Formation lies on the limbs (Fig. 2; section $\mathrm{AA}^{\prime}$ ).

The Ratta Fault is a reverse fault in the project area. The Ratta Fault is a northwest-southeast trending fault and cuts the southeastern limb of Pheran Dinpur anticline. In the project area, the Dhok Pathan Formation is thrusted over the Soan Formation (Fig. 3; cross sections, $\mathrm{AA}^{\prime}, \mathrm{BB}^{\prime}, \mathrm{CC}^{\prime}$, $\mathrm{DD}^{\prime}$ and $\mathrm{JJ}^{\prime}$ ). The attitude of the hanging wall block ranges from $\mathrm{N}^{\circ} 5^{\circ}$ $\mathrm{W} / 23^{\circ} \mathrm{NE}$ to $\mathrm{N} 55^{\circ} \mathrm{W} / 35^{\circ} \mathrm{NE}$ and the attitude of footwall block is $\mathrm{N} 48^{\circ}$ $\mathrm{W} / 32^{\circ} \mathrm{NE}$. The attitude of the fault plane is $\mathrm{N} 50^{\circ} \mathrm{W} / 61^{\circ} \mathrm{NE}$. The Ratta Fault is a reverse fault (Fig. 4h).

The shearing and crushing are also present along the fault zone (Fig. $4 \mathrm{~h}$ ). The fault breccia and gouge can be identified in the project area along the Ratta Fault. The drag folds are common along this fault.

\section{Conclusion}

The project area lies in the southeastern part of Hazara Kashmir Syntaxis. The Hazara Kashmir Syntaxis is an antiformal structure and the part of Himalayan foreland folds-and-thrust belt. The core of syntaxis possesses metamorphic and sedimentary rocks. The sedimentary rocks are mainly Neogene molasse deposits, formed by the late Tertiary Himalayan Orogeny.

In the project area, the thick cover sequence of sedimentary rocks ranging from Late Miocene to Recent age is exposed. These Neogene rocks are result of the collision of the Indian and Eurasian plates. The uplift of the Himalayan sediments caused erosion, transportation and deposition of these rocks in front of rising Himalayas. The project area is deformed due to the regional folds and faults. The fault is northwestsoutheast trending. The fault is reverse in nature. The folds of the area are northwest or southeast vergent and asymmetric in nature. These folds are open. These are northwest or southeast plunging folds. The major folds of the area are Pheran-Dinpur Anticline, Sadiqabad Syncline and Mirpur Syncline.

The major fault in the area is Ratta Fault. It is a splay fault of Jehlam Fault. It is a reverse fault.

\section{References}

[1] Akhtar, S.S., Ahmad, M., and Hussain, A., 2004, Geological mapping of the Dadyal area, Mirpur district AJK and part of the Rawalpindi District, Punjab, Pakistan: Pakistan Geological Survey, Geological map series, 6 (25).

[2] Ashraf, M., Chaudhary, M. N., 1984. Petrology of lower Siwalik rocks of Poonch area: Kashmir Journal of Geology, 2: 1-10

[3] Ashraf, M., Chaudhary, M.N., Qureshi, K. A., 1983. Stratigraphy of Kotli area of Azad Kashmir and its correlation with standard areas of Pakistan: Kashmir Journal of Geology, 1: 19-30.

[4] Baig, M.S., Lawrence, R.D., 1987. Precambrian to early Paleozoic orogenesis in the Himalaya: Kashmir Journal of Geology, 5 : 1-22.

[5] Bossart, P., Dietrich, D., Greco, A., Ottiger, R., Ramsay, J.G., 1988. The tectonic structure of the Hazara-Kashmir Syntaxis, southern Himalayas, Pakistan. Tectonics, 7: 273-279.

[6] Cotter, G. De. P. 1933. Geology of part of Attock district west of longitude $72^{\circ} 45^{\prime}$ E. Geological survey of India, Memoirs, 55(2): 63-161.

[7] Kravchenko, K. N., 1964. Soan Formation-Upper unit of Siwalik group in Potwar. Science and Industry, 2 (3): 230-233.

[8] Lewis, G.E., 1937. A new Siwaliks correlation (India): American Journal of Science, Series 5, 33 (195):191-204.

[9] Lydekker, R., (1876). Notes on geology of the Pir Panjal and neighboring Districts. Records of the Geological Survey of India, $9: 155$. 
[10] Meddlicot, H. B., (1864). Notes on the sub-Himalayan series of Jammu Hills. Records of the Geological Survey of India, 9:49.

[11] Monalisa and Khawaja, A.A., 2004. Structural trends and focal mechanism studies in the Potwar area with special emphasis on hydrocarbon exploration: Pakistan Journal of Hydrocarbon Research, 14: 49-59.

[12] Munir, M.H., Baig, M.S., 2006. Paleogene biostratigraphy of Tattapani, Kotli Azad Kashmir, northwest sub-Himalayas, Pakistan: Journal of Himalayan Earth Sciences, 39: 39-48.

[13] Pilgrim, G. E., 1913. Preliminary notes on a revised classification of the Tertiary fresh water deposits of India: Indian Geological Survey Record, 40 (3): 185-205.

[14] Shah, S.M.I., (2009). Stratigraphy of Pakistan. Memoirs of the Geological Survey of Pakistan, 22: 293-298.

[15] Wadia, D.N., 1928. The geology of the Poonch State (Kashmir) and adjacent portion of the Punjab: Geological Survey of India, Memoirs, 51 (2): 185-370.

[16] Wells, N.A., and Ginngerich, P.D., 1987. Paleoenvironmental interpretation of Paleogene strata near Kotli, Azad Kashmir, northeastern Pakistan: Kashmir Journal of Geology, 5: 23-42.

[17] Yasin, M., 2012. Structure and Stratigraphy of Chattroh, Siakh, Kanger, Mandhal and Palina areas of Azad Kashmir and Pakistan, Unpublished Thesis, Institute of Geology, University of Azad Jammu and Kashmir, Pakistan. pp. 39. 